\title{
Engagement of family members, corporate governance and social responsibility in family-owned enterprises
}

\author{
Abdul-Nasser El-Kassar \\ Department of Information Technology and Operations Management, \\ Lebanese American University, Beirut, Lebanon \\ Walid ElGammal \\ Department of Finance and Accounting, Lebanese American University, \\ Beirut, Lebanon, and \\ Josiane Fahed-Sreih \\ Department of Management Studies, Lebanese American University, \\ Beirut, Lebanon
}

\begin{abstract}
Purpose - With the increasing awareness and recognition of the importance of corporate governance (CG), its practices and mechanisms along with their effect on performance and general organization's behavior have become of interest for many scholars. The purpose of this paper is to examine the relationship between CG, with a focus on the board of directors (BOD) and the audit committee, and the level of corporate social responsibility (CSR) practices toward health, refugees, community, and environment.

Design/methodology/approach - Data were collected through a questionnaire distributed to 203 employees working at family-owned enterprises (FOE) in Lebanon. SmartPLS 3.0, statistical software for structural equation modeling, was used to analyze data.

Findings - The results indicate that the audit committee component of $C G$ has a significant positive impact on CSR dimension practices toward health, refugees, and community and environment. Furthermore, family members' engagement in the board of directors and decision making plays a moderating role on the relationship between the audit committee and CSR practices toward health, community, and environment, as well as the relationship between the BOD and CSR toward community and environment.

Originality/value - The role of family members' engagement in the effectiveness of CG and CSR practices FOE is studied.

Keywords Corporate social responsibility, Corporate governance, Engagement of family members,

Family-owned enterprises

Paper type Research paper

\section{Introduction}

Corporate governance (CG) is one of the most sought out topics in the organizational field and a continuing research focus amongst scholars, business journalists, and policy makers (Dalton et al., 2007; Hambrick et al., 2008). Several studies have been done on CG being a front-line topic. It refers to a system of mechanisms, processes, practices, and rules by which corporations are monitored, controlled, and directed. CG, in essence, involves the balance of

(c) Abdul-Nasser El-Kassar, Walid ElGammal, and Josiane Fahed-Sreih. Published by Emerald Publishing Limited. This article is published under the Creative Commons Attribution (CC BY 4.0) licence. Anyone may reproduce, distribute, translate and create derivative works of this article (for both commercial and non-commercial purposes), subject to full attribution to the original publication and authors. The full terms of this licence may be seen at http://creativecommons.org/licences/by/4.0/legalcode

This research is funded by the Lebanese American University.
\end{abstract}

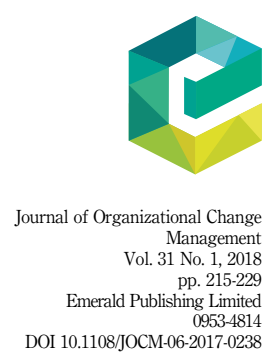

Received 15 June 2017 Revised 8 November 2017 Accepted 1 December 2017 
JOCM

31,1

216

the interests of the various stakeholders of a corporation. These comprise the shareholders, employees, management, suppliers, customers, and the community. Thus, since it incorporates virtually every scope of management, from action plans to performance control and corporate disclosure, it can play a significant role in terms of corporate social responsibility (CSR).

CSR, also referred to as sustainable responsible business (Wood, 1991), is a management process involving the efforts that a corporation takes to behave responsibly toward society. The CSR policy works as a supervisory mechanism where businesses display and warrant their vigorous compliance with the law and ethical standards. "CSR" is a term that became popular in the 1960s and has persisted to be used extensively in the coverage of moral as well as legal responsibility (De George, 2011).

Even though the CSR principles have existed for a long time, the concept has beheld an amazing dominance and renaissance in recent years (Jamali et al., 2009). Many corporations, especially in the USA, Europe, and Japan have been known to be leaders of CSR, such as Microsoft, Walt Disney Company, Google, BMW, and Sony, among others (Smith, 2014). In developing countries, however, the principle of CSR, if existent at all, is just at this time attempting to catch up to the rest of the world. This is the case of Lebanon, a small country situated alongside the eastern shore of the Mediterranean Sea, which recently has been setting up plans to ensure a well-fit CSR notion.

The performance of the Lebanese's corporations compared to their actual potential is deliberated to be low because of the multiple series of scandals and collapses that this country has witnessed over the years. The grouping of citizens by religion plays a precarious part in Lebanon's social and political aspects and has been recognized as the root to the country's most hostile clashes (Jamali and Mirshak, 2010). Thus, unsurprisingly, the situation in Lebanon has its own distinctive features. Additionally, most Lebanese companies are "family-owned" which tend to run and manage their business by themselves instead of following a definite set of policies, not recognizing the importance of CG and social responsibility. These family businesses in Lebanon represent 85 percent of the private sector, accounting for 1.05 million out of 1.24 million jobs (Kaslow, 2006). However, as Lebanon integrates with the world economy, the organization and structure of its businesses and productive institutions ought to be revised (Saidi, 2004). To contribute to society, Lebanese corporations have to consider moving toward a consistent and ethical way of conducting business. A few leaders in the country have acknowledged the prominence of the CSR concept and have begun adopting and promoting it, such as BLOM BANK SAL, which is considered one of the Middle East's top banks. Conversely, only a limited number of studies have been conducted to evaluate companies' social performance in the Lebanese context.

On the other hand, during the long process of recovery through a transition economy after more than 30 years of the civil Lebanese war, the family business structure became insulated and often the only intact socio-economic institution that has the capabilities of supporting entrepreneurial activities. Family businesses in Lebanon perform a vital role being the contributors to innovation opportunities and being the core players of local economic development (International Finance Corporation, 2017). Moreover, Lebanon has been proving its importance in being the "laboratory" of entrepreneurship, through its family businesses, mainly divided into small and medium enterprises (Fahed-Sreih et al., 2010). Based on a study conducted by Fahed-Sreih et al. (2010), 80 percent of surveyed Lebanese entrepreneurs were the members of leading family firms, thus proving that 80 percent of Lebanese family firms are leading in their fields. Some of the basic aspects that cause these firms to be successful and leading are the attainment of resources that aid in the support for the survival of the business and the availability of succession as more family members should be involved for the continuity and progress of the activities. 
Generally speaking, entrepreneurial Lebanese families make what the Lebanese economy needs for its growth, making a successful transition from a period of war to a period of free market economy (Fahed-Sreih, 2008). There have been only few studies evaluating the social performance of businesses in the Lebanese context. Family-owned businesses are philanthropic in nature. Strategic CSR procedures are lacked in most of these businesses, while different CSR practices are implemented irregularly and in intermittent frequencies.

Many literatures discuss the CSR concept, proving its importance to the business world. This study aims to prove that family-owned enterprises (FOE) with good CG tend to be more engaged in CSR than those with weak CG, whereby a high involvement of family members in the business tend to strengthen the relationship between CG and CSR. For this purpose, the data will be collected through a questionnaire which will be distributed to several corporations in Lebanon. The results will be obtained through a statistical analysis conducted using statistical computer packages. In addition to this, the study will provide some recommendations to improve and expand the CSR concept within the Lebanese corporations.

\section{Literature review}

The area of CG discourses an inclusive diversity of subjects, concentrating on financial performance (Dalton et al., 2003; Tosi et al., 2000). Nevertheless, classic corporate scandals such as the cases of Enron and Arthur Andersen raise the debate over whether enterprises ought to embrace social factors as part of their corporate goals or continue to emphasize exclusively on maximizing earnings (Margolis and Walsh, 2003). This, in turn, led to enduring concerns augmenting over how firms are governed and what governance elements may effectively influence social business behavior.

The results of a study conducted by Jo and Harjoto (2011) show that the probability of choosing to adopt the CSR concept is positively related to governance characteristics such as board leadership, board independence, structural ownership, and audit monitoring. According to Salloum et al. (2013), the foremost downside of family-owned businesses in Lebanon is the lack of independence required to monitor the firm's activities. It is believed that in Lebanon and the Arab world, family businesses, instead of being market-driven pursuits, are a means to heightening a family's social status (Kaslow, 2006).

CG in Lebanon is not yet well established (Elkassar et al., 2015). But in the past few years, the government has undertaken some steps to changing that fact. Unfortunately, prevailing legal and regulatory requirements lack several vital CG protection codes, specifically with respect to the composition and operation of boards of directors (Salloum et al., 2013). Moreover, the trend of CSR has been gaining increased attention in the Lebanese workplace. Since the top managers make the strategic decisions, their part in integrating social practices must not be overlooked. The results of the study by Jamali et al. (2015) reveal that CSR in the Lebanese organizations is a direct mirror of the owner's values and that they play a very essential role in determining the nature and focus of CSR in their respective enterprises. According to Jamali et al. (2015), CSR does exist in the Lebanese context. However, family-owned businesses are believed to be philanthropic in nature, practicing genuine CSR every now and then rather than following a strategic CSR objective cohesive in the organization's mission and vision. According to Charbaji (2009), valuable CG and CSR can be embraced in Lebanon and other developing countries through initiating new corporate principles within organizations and acknowledging the relations among environmental, social, and economic standards.

\section{Theoretical framework}

CSR benefits all stakeholders in appropriate CG, and thus the importance of a stakeholder theory's approach (Gill, 2008). CSR has been shown to be essential in many organizations,

Family-owned enterprises 
JOCM 31,1 as its approach positively influences CG, even though it is achieved at the expense of financial outcomes (Tuan, 2012).

On the other hand, CG emerged from the problems associated with the separation of ownership and control that is seen in the modern corporate form of organizations (Denis, 2001). The separation of ownership and control is the basis for the agency problem dealing with the most adapted theory for CG, the agency theory. Claessens and Yurtoglu (2013) identify a primary cause of the agency problem to be the multiple steps that separate shareholders from the final user of their capital. Therefore, both the agency theory and the stakeholder theory, which are the two main theories that are used when discussing CG and CSR, cover the conceptual framework of this study. Other theories are derived based on different variables including the structure of the board of directors (BOD), the audit committee, and relations among managers (Nicolae and Violeta, 2013).

Agency theory. Adam Smith's Wealth of Nation describes the fundamental problem as follows: "Being the manager of other peoples' money (rather than their own) [...] it cannot be expected that they should watch over it with the same anxious vigilance [...]" (Smith, 1937).

This concept described above is referred to as an "agency problem." An agency problem emerges from the agency theory, concerned with relationships between two parties: the principal and the agent. This relationship is called the "agency relationship." It arises whenever an individual depends on the action of another individual. The principal hires the agent to perform a certain task. Whenever the principal gives control and/or decision-making authority to the agent, an agency relationship arises (Zeckhauser and Pratt, 1985). Agency theory, which was first introduced by Stephen Ross and Barry Mitnick in 1973 (Mitnick, 2013), deals with solving problems (agency problems) that arise from an agency relationship. Agency problems also arise whenever the agent (mainly managers) have incentives to pursue their own interests on the expense of the principal (usually shareholders or owners) (Agrawal and Knoeber, 1996).

More recently, Dalton et al. (2007) introduced three principal means to minimize agency problems: board independence, the market for corporate control, and agent equity ownership. The first mean, considered as improving the monitoring of managers by directors; the second mean refers to active acquisition and merger market which disciplines bad-behaving managers; while the third mean leads managers to embrace shareholders' interests, given their shared ownership of the firm (Dalton et al., 2007). Thus, it is theorised that good CG is expected to reduce the agency problem and weaken the managers' motivation to prioritize their own interests at the expense of shareholders (Chen et al., 2012). As a result, this theory has influenced policy making and codes of good CG practices.

Stakeholder theory. In his book Strategic Management: A Stakeholder Approach, Edward Freeman $(1984,2010)$, states that the corporation exists for the purpose of serving its stakeholders. A stakeholder is any party that should be considered in the decision-making process of any organization. These include the management, the shareholders, the suppliers, the employees, the customers, the community, and even the competitors (Schilling, 2000 in Grant, 2003), and every person whose interests is at stake when considering the success or failure of the corporation (Mayer, 2013). A stakeholder is any person or group who have claim on the firm (Freeman, 1984; Argandona, 2011). Gareth Jones (2010) defines stakeholders as "people who have interest, claim, or stake in an organization, in what it does, and in how well it performs" (p. 50). The stakeholder theory suggests that managers have to serve a network of relationships known as the stakeholders. This was described by Chester Bernard and Henry L. Grant who described the responsibility of managers to include fulfilling the interests of stakeholder (Grant, 2003). After the publication of R. Edward Freeman's (1984) book, the stakeholders' approach has been studied more into details emphasizing more on CG (Donaldson and Preston, 1995). 
There is a symbiotic relationship between the firm and each of the investors, political groups, customers, communities, employees, trade associations, suppliers, and governments; all known as stakeholders. Stakeholder theory indicates that corporations conduct CSR not only for the purpose of generating profits and abide by laws and values, but also because they aim to be ethical and socially supportive (Carroll, 1979, 1991, 1999). Hence, the importance of this theory is the fact that it seeks to address the often passed over sociological question: how do organizations affect society? (Stern and Barley, 1996).

\section{Conceptual framework}

CG is not a term; it is a concept with no unified definition. The broadest clear definition of CG is provided by the Cadbury (1992) committee as being a set of mechanisms through which firms operate when ownership is separated from management. On the other hand, in their famous article a survey of CG, Shleifer and Vishny (1997) defined CG as the ways in which suppliers of finance to corporations assure themselves of getting a return on their investment. Many other researchers described CG from different views, including its reflections on economic, financial, marketing, and accounting fields; but its main focus has always been associated with management, particularly, the BOD. CG and CSR have mutual symbiotic roles. CSR is a management process involving the efforts that a corporation takes to behave responsibly toward society; hence, we can consider CSR as an integral part of CG.

Through improvements and research done on CG, the inclusion of CSR is being noticed to increase (Claessens, 2003). According to Jamali et al. (2008), both the fields of CG and CSR strive to articulate a corporate institution's commitment to its stakeholders and the nature of its interaction with the community in general. CSR is now essential in incorporating social and environmental concerns.

CSR began in developed countries, mainly in large corporations like Microsoft, Walt Disney, Google, and many others. Nowadays, it is becoming a major goal of institutions in all countries in order to be able to catch up with the competing market, since the image and ethical background of any corporation are essential for its success. Although CSR in developing countries "is yet to achieve full potential" (Idemudia, 2011), its increasing awareness wave has doubtlessly reached, at least, the industry leaders in these economies. It is strongly significant to examine CSR practices of the firms in such countries, knowing the powerful impact of these practices on needy and disadvantaged communities (E Ite, 2004). According to Jamali and Mirshak (2010), the performance in Lebanese corporations is considered low overall compared to the potential and capabilities of such firms. Both adequate CG and CSR are needed.

\section{Objectives of the study}

This study aims at recognizing the different levels of CG and CSR espoused by various FOEs in Lebanon. Moreover, this paper will examine the existence of a positive relationship between CG and CSR. It will explore if higher CG results in greater CSR. The particular components that promote CSR are to be identified, along with the moderating effects of family engagement on these relationships.

\section{Hypotheses development}

In their study, Khan et al. (2013) concluded that CG characteristics have significant positive impacts on CSR disclosure, which in turn plays a vital role in ensuring the organization's legitimacy. It was also found that better-governed corporations tend to have increased CSR practices and a more socially responsible agenda (Ntim and Soobaroyen, 2013). Moreover, Money and Schepers (2007) revealed a significant alignment between developing CG structures and CSR programs. For this reason, the following 
JOCM

31,1

220

hypotheses are formulated, taking the BOD and the audit committee as the two CG components understudy:

H1. There is a positive relationship between the BOD component of CG and CSR practices.

H2. There is a positive relationship between the audit committee component of CG and CSR practices.

Furthermore, according to Jia and Zhang (2013), a higher probability of charity and donation was found to be associated to higher managerial ownerships. Similarly, Coffey and Wang (1998) demonstrated a positive relationship between managerial control and corporate philanthropy and social performance. In line with this literature, $H 1$ and $H 2$ are expanded (Figure 1) to examine the relationship between each CG and CSR component separately as follows:

H1a. There is a positive relationship between board of director and CSR toward health.

H1b. There is a positive relationship between board of director and CSR toward refugees.

H1c. There is a positive relationship between board of director and CSR toward community and environment.

H2a. There is a positive relationship between audit committee and CSR toward health.

$H 2 b$. There is a positive relationship between audit committee and CSR toward refugees.

H2c. There is a positive relationship between audit committee and CSR toward community and environment.

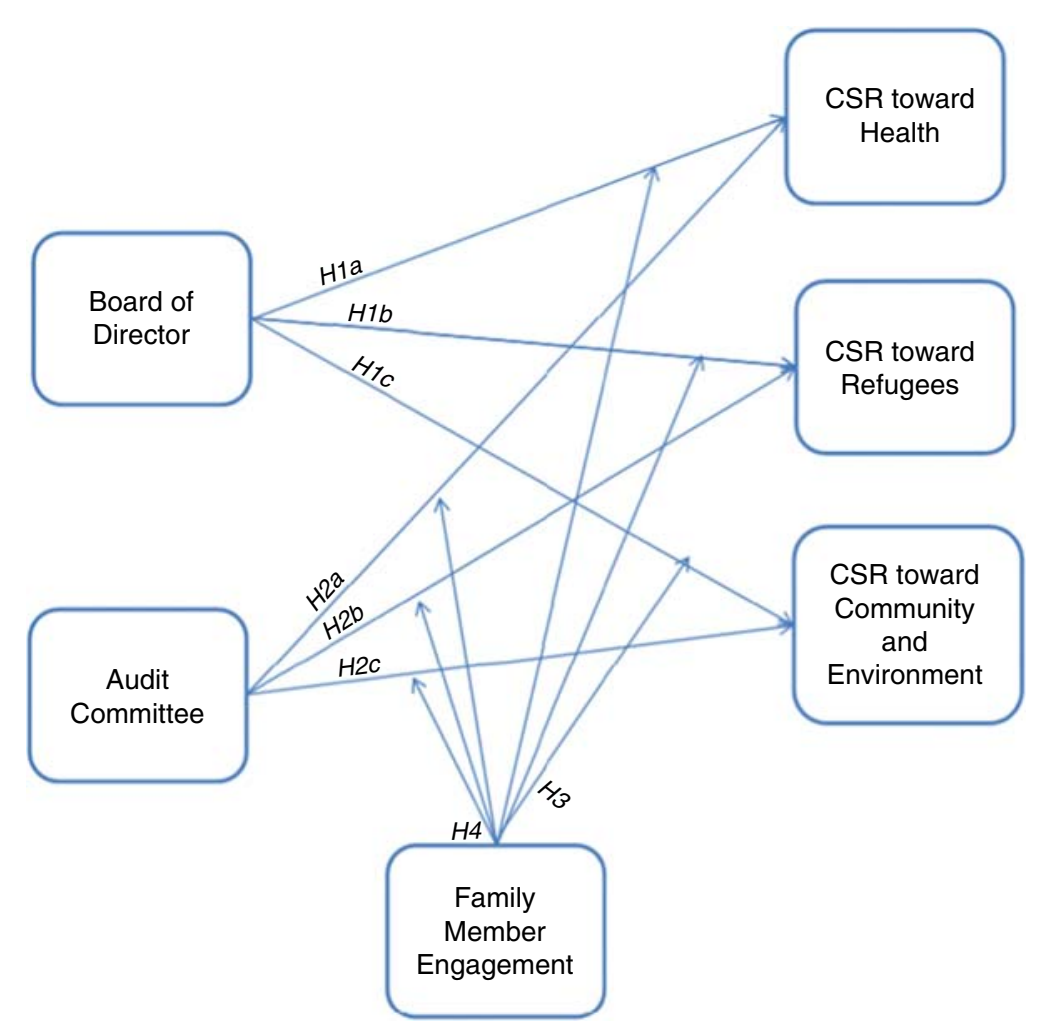

Figure 1.

Conceptual model 
Furthermore, Carney (2005) argued that the competitive advantage of family-controlled firms lies within their system of CG which facilitates the creation and the utilization of social capital. And since FOEs in Lebanon are philanthropic by nature, it is expected that this high involvement in management and control by the family members plays a mediating role on the relationship between CG and CSR. As a result, the following hypotheses are developed:

H3. Family member engagement moderates the relationship between the BOD component of CG and CSR practices.

H4. Family member engagement moderates the relationship between the audit committee component of CG and CSR practices.

In order to study the mediating effect of family members on the relationships between each of the two CG components along with each of the three CSR components, H3 and H4 are expanded accordingly to become:

$H 3 a$. Family member engagement moderates the relationship between the effectiveness of BOD and CSR toward health.

$H 3 b$. Family member engagement moderates the relationship between the effectiveness of BOD and CSR toward refugees.

$H 3 c$. Family member engagement moderates the relationship between the effectiveness of BOD and CSR toward community and environment.

H4a. Family member engagement moderates the relationship between the effectiveness of audit committee and CSR toward health.

$H 4 b$. Family member engagement moderates the relationship between the effectiveness of audit committee and CSR toward refugees.

H4c. Family member engagement moderates the relationship between the effectiveness of audit committee and CSR toward community and environment.

\section{Methodology}

Data for this quantitative cross-sectional study were collected through a self-administered survey. The questionnaire was distributed to employees working in FOEs operating in Lebanon. Most of these FOEs were selected from the database of the Institute of Family and Entrepreneurial Business, Lebanese American University. Out of the 320 questionnaires sent via e-mail, 212 were returned, in which 203 were usable, yielding a response rate of 63.43 percent.

The questionnaire is separated into three parts totaling 30 questions. The first three parts consist of five-point Likert scale questions (from strongly agree to strongly disagree), while the last part is made up of choice determinant questions. The sections are as follows:

(1) Items examining CG: out of the 14 items that were used by El-Kassar et al. (2014) to examine the requirements and characteristics of CG, 12 items were selected for this study shown in the list (CG constructs) below.

(2) Items testing CSR: based on Khan's (2010) scale of the elements of CSR (toward health, refugees, community, and environment), 13 items were selected for this study shown in the list (CSR constructs) below.

(3) Questions regarding corporate demographics (size of the company, size of the BOD, frequency of annual board meetings, change of average annual sales, and debt to equity ratio).

Family-owned enterprises 
JOCM

31,1

222

Items of the CG constructs:

BRDDIR1: There are enough independent members in the BOD.

BRDDIR2: The board members have sufficient knowledge and experience.

BRDDIR3: The board members have enough time to serve effectively.

BRDDIR4: The number of board meetings held per annum is sufficient

ADTCOM1: Audit committee is formed of independent members.

ADTCOM2: Number of financially literate audit committee members is sufficient.

ADTCOM3: Audit committee approves the internal audit plan and major changes to the plan.

ADTCOM4: Audit committee reviews the internal audit reports.

ADTCOM5: Audit committee appoints, evaluates the performance, and dismisses the head of internal audit.

ADTCOM6: Good collaboration of work between internal auditors and audit committee.

ADTCOM7: Internal control procedures as described in the policy procedures manuals are effective.

ADTCOM8: Internal control procedures as described in the policy procedures manuals are actually applied.

Items of the CSR constructs:

HEALTH1: Health assistance of underprivileged and disabled children.

HEALTH2: Assisting cancer hospitals.

HEALTH3: Women and children's hospitals to bear the operational costs.

REFUGE1: Providing shelter for war refugees.

REFUGE2: Distributing of warm clothes among the war-affected people.

REFUGE3: Distributing food among the war-affected people.

CMTENV1: Different sports organizations.

CMTENV2: Sponsoring different national and international games and events.

CMTENV3: Improvement of street children's condition.

CMTENV4: Planting trees to make the country green.

CMTENV5: Supporting public/private actions designed to protect the environment.

CMTENV6: Operating costs of environmental friendly equipment and facilities.

CMTENV7:Promoting environmental awareness to the community through promotional tools.

\section{Research design}

The paper is a cross-sectional quantitative study. All results will be numerically measured and interpreted using different statistical computer packages. Moreover, the paper is a combination of both descriptive and exploratory natures. An exploratory study, however, is more emphasized since the research establishes and explores a relationship between CG and CSR.

\section{Sample and questionnaire}

The target population of the research is FOEs operating in Lebanon. A questionnaire of both choice determinant and Likert scale-type questions is used to conduct this research. The questionnaire will be distributed to different FOEs by the Institute of Family-Owned Businesses in Lebanon.

\section{Data analysis results}

Demographics

The results of the participants' demographics are summarized in Table I. 
Outer model

All the items of CSR showed a significant loading $(\phi$-value $=0.000)$ and were used to obtain a score for each dimension (health, refugees, and community and environment scores). Similarly, all components of CG showed significance having a $p$-value of 0.000 . The two CG items were used to obtain individual scores: BOD score and audit committee score. The factor loading for each of the latent constructs is displayed in Table II.

\section{The measurement model}

The reliability outcomes are shown in Table III. The results reveal that the measures used are reliable as all Cronbach's $\alpha$ and composite reliability values are well above 0.7 , ranging between 0.849 and 0.963. Additionally, following the guidelines of Fornell and Larcker (1981), the average variance extracted (AVE) for each measure surpasses 0.5.

In addition to this, Table IV displays the outcomes of testing the discriminant validity of the variable constructs. The numbers in the matrix diagonals correspond to the square
Family-owned enterprises

223
Size of the company (number of employees)

Size of the board of directors

(number of members)

Frequency of annual BOD meetings
(1) $>1,000(22.2 \%)$; (2) 201-1,000 (38.9\%); (3) 50-200 (20.2\%);
(4) $<50(18.7 \%)$
(1) $1-4$ (37.4\%); (2) 5-10 (30.0\%); (3)> $10(32.5 \%)$
(1) $1-3(12.3 \%)$; (2) $4-6(56.7 \%)$; (3) $>6(31.0 \%)$

Table I. Demographics

\begin{tabular}{|c|c|c|c|c|c|c|}
\hline $\begin{array}{l}\text { Latent } \\
\text { variables }\end{array}$ & $\begin{array}{l}\text { Manifest variables } \\
\text { label }\end{array}$ & $\begin{array}{l}\text { Original } \\
\text { sample }\end{array}$ & $\begin{array}{c}\text { Lower bound } \\
(95 \%)\end{array}$ & $\begin{array}{l}\text { Upper bound } \\
(95 \%)\end{array}$ & $p$-value & \\
\hline \multicolumn{7}{|c|}{ Corporate governance } \\
\hline \multirow{4}{*}{ BRDDIR } & BRDDIR1 & 0.705 & 0.587 & 0.705 & 0.000 & \\
\hline & BRDDIR2 & 0.863 & 0.810 & 0.863 & 0.000 & \\
\hline & BRDDIR3 & 0.886 & 0.839 & 0.886 & 0.000 & \\
\hline & BRDDIR4 & 0.856 & 0.797 & 0.856 & 0.000 & \\
\hline \multirow[t]{8}{*}{ ADTCMT } & ADTCOM1 & 0.780 & 0.714 & 0.836 & 0.000 & \\
\hline & ADTCOM2 & 0.894 & 0.854 & 0.924 & 0.000 & \\
\hline & ADTCOM3 & 0.906 & 0.872 & 0.934 & 0.000 & \\
\hline & ADTCOM4 & 0.935 & 0.911 & 0.953 & 0.000 & \\
\hline & ADTCOM5 & 0.836 & 0.776 & 0.896 & 0.000 & \\
\hline & ADTCOM6 & 0.886 & 0.848 & 0.917 & 0.000 & \\
\hline & ADTCOM7 & 0.886 & 0.854 & 0.913 & 0.000 & \\
\hline & ADTCOM8 & 0.875 & 0.815 & 0.923 & 0.000 & \\
\hline \multicolumn{7}{|c|}{ Corporate social responsibility } \\
\hline \multirow[t]{3}{*}{ HEALTH } & HEALTH1 & 0.882 & 0.829 & 0.925 & 0.000 & \\
\hline & HEALTH2 & 0.943 & 0.923 & 0.962 & 0.000 & \\
\hline & HEALTH3 & 0.937 & 0.906 & 0.962 & 0.000 & \\
\hline \multirow[t]{3}{*}{ REFUGE } & REFUGE1 & 0.911 & 0.869 & 0.944 & 0.000 & \\
\hline & REFUGE2 & 0.950 & 0.925 & 0.969 & 0.000 & \\
\hline & REFUGE3 & 0.899 & 0.805 & 0.957 & 0.000 & \\
\hline \multirow[t]{7}{*}{ CMTENV } & CNTENV1 & 0.623 & 0.397 & 0.757 & 0.000 & \\
\hline & CNTENV2 & 0.551 & 0.291 & 0.711 & 0.000 & \\
\hline & CNTENV3 & 0.698 & 0.551 & 0.802 & 0.000 & \\
\hline & CNTENV4 & 0.896 & 0.829 & 0.931 & 0.000 & \\
\hline & CNTENV5 & 0.949 & 0.908 & 0.968 & 0.000 & Table II. \\
\hline & CNTENV6 & 0.901 & 0.860 & 0.932 & 0.000 & Outer model \\
\hline & CNTENV7 & 0.958 & 0.928 & 0.972 & 0.000 & measurements \\
\hline
\end{tabular}


JOCM

31,1

224

roots of the AVEs. In all of the cases shown, these numbers are greater than the off-diagonal elements in their respective row and column. This supports the discriminant validity of our scales.

\section{The structural models}

Figure 2 depicts the results of the structural model with the impact of the moderator variable being omitted.

The bootstrap test was conducted to determine the significance of the path coefficients. The results shown in Table $\mathrm{V}$ indicate that $H 2 a, H 2 b$, and $H 2 c$ were all supported. Hence, there was an overwhelming evidence to conclude that audit committee component of CG has a significant positive impact on CSR toward health $(\beta=0.375, p$-value: 0.000$)$, toward refugees $(\beta=0.458, p$-value: 0.000$)$, and toward community and environment $(\beta=0.379$, $p$-value: 0.000 ). As for the BOD component of $\mathrm{CG}$, the results did not find significant impact on any of the CSR categories.

To test the moderating effect of the engagement of family members on the relationship between CG and CSR, cluster analysis was performed on two items: family members participating in BOD meetings; and family members which are involved in the decisionmaking process. The analysis resulted in three groups or clusters, high, moderate, and low engagement. The moderating effects will be tested only on the high and low engagement groups. The first group represents FOEs whose family members are highly engaged in the decision making process. This cluster contains 72 FOEs of our sample. On the other hand, the group of companies with low family members engagement in the decision making process consists of 68 FOEs of our sample. For each of the two items of engagement, the analysis of variance test (Table VI) showed significant difference in means among the three groups.

Using the above clustering, a multi-group analysis was conducted to determine whether the relationships in the above model (Figure 1) significantly differ among FOEs whose family members engage more in the decision making process and those who do not. The results (Table VII) show differences in the significance of the relationships among the two groups occur in the impact of the audit committee on CSR toward the community and environment ( $\phi$-value $=0.008$ for high engagement and 0.169 for low engagement), as well as toward health ( $\phi$-value $=0.001$ for high engagement and 0.230 for low engagement). These results provide evidence for supporting $H 4 c$ and $H 4 a$, respectively. This indicates

Composite reliability

\begin{tabular}{lccc}
\hline & Cronbach's $\alpha$ & Composite reliability & Average variance extracted (AVE) \\
\hline ADTCOM & 0.956 & 0.963 & 0.767 \\
BRDDIR & 0.849 & 0.898 & 0.690 \\
CMTENV & 0.920 & 0.929 & 0.659 \\
HEALTH & 0.910 & 0.944 & 0.848 \\
REFUGE & 0.910 & 0.943 & 0.846 \\
\hline
\end{tabular}

\begin{tabular}{lccccc}
\hline Latent variables & ADTCOM & BRDDIR & CMTENV & HEALTH & REFUGE \\
\hline ADTCOM & 0.876 & & & & \\
BRDDIR & 0.778 & 0.831 & & & \\
CMTENV & 0.340 & 0.245 & 0.812 & & \\
HEALTH & 0.515 & 0.471 & 0.421 & 0.921 & \\
REFUGE & 0.472 & 0.374 & 0.401 & 0.684 & 0.920 \\
& & & & &
\end{tabular}

Table IV.

Discriminant validity of variable constructs (BRD as dependent variable) 


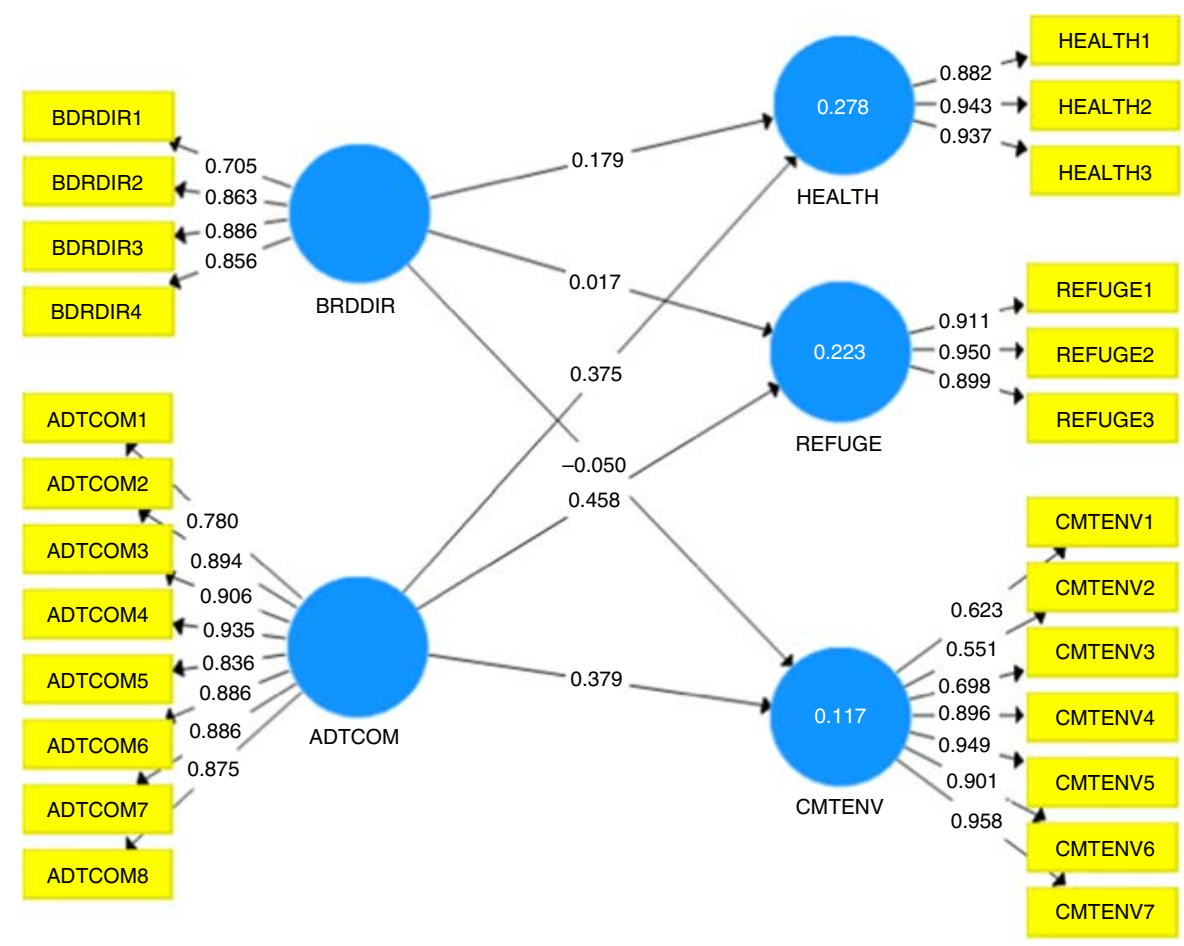

Family-owned enterprises

Figure 2.

Structural model results (without moderation effects)

\begin{tabular}{lcccc}
\hline & Sample mean & SD & $t$-statistics & $p$-values \\
\hline ADTCOM $\rightarrow$ CMTENV & 0.384 & 0.093 & 4.081 & 0.000 \\
ADTCOM $\rightarrow$ HEALTH & 0.377 & 0.101 & 3.708 & 0.000 \\
ADTCOM $\rightarrow$ REFUGE & 0.469 & 0.101 & 4.553 & 0.000 \\
BRDDIR $\rightarrow$ CMTENV & -0.047 & 0.103 & 0.486 & 0.627 \\
BRDDIR $\rightarrow$ HEALTH & 0.182 & 0.111 & 1.611 & 0.108 \\
BRDDIR $\rightarrow$ REFUGE & 0.010 & 0.112 & 0.155 & 0.877
\end{tabular}

Notes: *** Significant at 0.05 and 0.01 levels, respectively

Table V. Structural model path coefficients results

\begin{tabular}{lccccccc}
\hline & \multicolumn{1}{c}{$\begin{array}{c}\text { Cluster } \\
\text { Mean square }\end{array}$} & df & Mean square & df & $F$ & Sig. & \\
\hline Engagement in board meetings & 43.810 & 2 & 0.173 & 200 & 252.91 & 0.000 & Table VI. \\
Participate in decision making & 18.398 & 2 & 0.062 & 200 & 295.69 & 0.000 & Cluster analysis \\
\hline
\end{tabular}

that in the presence of family members' influence, a more effective audit committee leads to higher engagement in CSR toward community, environment, and health. Also, there is a difference in the significance of the impact of the BOD on CSR toward health with $p$-value $=0.786$ for high engagement and 0.042 for low engagement. However, in this case, the impact tends to be higher for the low engagement group and therefore hypothesis $H 3 \mathrm{c}$ is supported. It is worth noting that the impact on the refugees is significant regardless of the 


\begin{tabular}{|c|c|c|c|c|c|c|c|c|c|}
\hline \multirow{2}{*}{$\begin{array}{l}\text { JOCM } \\
31,1\end{array}$} & & \multicolumn{4}{|c|}{ High } & \multicolumn{4}{|c|}{ Low } \\
\hline & & $\begin{array}{l}\text { Path } \\
\text { coef. }\end{array}$ & $\mathrm{SE}$ & $t$-value & $p$-value & $\begin{array}{l}\text { Path } \\
\text { coef. }\end{array}$ & SE & $t$-value & $p$-value \\
\hline \multirow{4}{*}{226} & ADTCOM $\rightarrow$ CMTENV & 0.424 & 0.160 & 2.649 & 0.008 & -0.468 & 0.340 & 1.377 & 0.169 \\
\hline & ADTCOM $\rightarrow$ HEALTH & 0.486 & 0.144 & 3.368 & 0.001 & 0.272 & 0.226 & 1.201 & 0.230 \\
\hline & ADTCOM $\rightarrow$ REFUGE & 0.368 & 0.165 & 2.228 & 0.026 & 0.452 & 0.225 & 2.013 & 0.045 \\
\hline & BRDDIR $\rightarrow$ CMTENV & 0.052 & 0.160 & 0.326 & 0.745 & 0.195 & 0.257 & 0.756 & 0.450 \\
\hline Table VII. & BRDDIR $\rightarrow$ HEALTH & 0.044 & 0.163 & 0.271 & 0.786 & 0.420 & 0.206 & 2.042 & 0.042 \\
\hline Multi-group analysis & BRDDIR $\rightarrow$ REFUGE & 0.063 & 0.193 & 0.326 & 0.745 & 0.225 & 0.193 & 1.166 & 0.244 \\
\hline
\end{tabular}

level of engagement. This could be due to the current refugee status in Lebanon induced by the Syrian conflict. The results show differences in the significance of the impact of the BOD on CSR toward health among the two groups.

\section{Conclusion}

Although CG may not have a unique definition, it is viewed as a framework and set of guidelines in order to achieve more effective results. The BOD and the audit committee presence and practices are high-important components of CG through which a company can exercise full control over its resources as well as contribute to its community maximizing by that the overall benefit of all stakeholders. Engaging in such contributions that aim to increase the well-being of the society and the environment is considered as a CSR practice. In this study, the relationships between each of the two CG components (board of directors and audit committee) and the three CSR dimensions (toward health, refugees, and community and environment) were studied. Moreover, the mediating role of family members' engagement in the business on these relationships was examined. Data were collected through a questionnaire answered by employees of FOE operating in Lebanon. The results showed that the audit committee component of CG has a significant positive impact on the three CSR dimensions. Furthermore, family members' engagement plays a mediating role on the relationship between the audit committee and CSR practices toward both health and community and environment as well as on the relationship between the BOD and CSR toward community and environment.

This study, nonetheless, took only FOE into consideration when planning the sample. Future research can study the same concept in other types of companies such as government-owned and publicly listed companies in Lebanon.

\section{References}

Agrawal, A. and Knoeber, C.R. (1996), "Firm performance and mechanisms to control agency problems between managers and shareholders", Journal of Financial and Quantitative Analysis, Vol. 31 No. 3, pp. 377-397.

Argandona, A. (2011), "Stakeholder theory and value creation", No. D/922, IESE Business School, Barcelona.

Cadbury, A. (1992), "Report of the committee on the financial aspects of corporate governance", Vol. 1, GEE, London.

Carney, M. (2005), "Corporate governance and competitive advantage in family-controlled firms", Entrepreneurship Theory and Practice, Vol. 29 No. 3, pp. 249-265.

Carroll, A. (1979), "A three-dimensional conceptual model of corporate social performance”, Academy of Management Review, Vol. 4 No. 4, pp. 497-505. 
Carroll, A. (1991), "The pyramid of corporate social responsibility: toward the moral management of organizational stakeholders", Business Horizons, Vol. 34 No. 4, pp. 39-48.

Carroll, A. (1999), “Corporate social responsibility”, Business \& Society, Vol. 38 No. 3, pp. 268-295.

Charbaji, A. (2009), "The effect of globalization on commitment to ethical corporate governance and corporate social responsibility in Lebanon", Social Responsibility Journal, Vol. 5 No. 3, pp. 376-387.

Chen, C.X., Lu, H. and Sougiannis, T. (2012), "The agency problem, corporate governance, and the asymmetrical behavior of selling, general, and administrative costs", Contemporary Accounting Research, Vol. 29 No. 1, pp. 252-282.

Claessens, S. (2003), "Corporate governance and development", Global Corporate Governance Forum, Focus 1, Washington, DC.

Claessens, S. and Yurtoglu, B.B. (2013), "Corporate governance in emerging markets: a survey", Emerging Markets Review, Vol. 15 No. C, pp. 1-33.

Coffey, B.S. and Wang, J. (1998), "Board diversity and managerial control as predictors of corporate social performance", Journal of Business Ethics, Vol. 17 No. 14, pp. 1595-1603.

Dalton, D.R., Hitt, M.A., Certo, S.T. and Dalton, C.M. (2007), "The fundamental agency problem and its mitigation", Academy of Management Annals, Vol. 1 No. 1, pp. 1-64.

Dalton, D.R., Daily, C.M., Certo, S.T. and Roengpitya, R. (2003), "Meta-analyzes of financial performance and equity: fusion or confusion?", Academy of Management Journal, Vol. 46 No. 1, pp. 13-26.

De George, R.T. (2011), Business Ethics, Dorling Kindersley, Licensees of Pearson Education in South Asia.

Denis, D.K. (2001), "Twenty?five years of corporate governance research... and counting”, Review of Financial Economics, Vol. 10 No. 3, pp. 191-212.

Donaldson, T. and Preston, L.E. (1995), "The stakeholder theory of the corporation: concepts, evidence, and implications", Academy of Management Review, Vol. 20 No. 1, pp. 65-91.

E Ite, U. (2004), "Multinationals and corporate social responsibility in developing countries: a case study of Nigeria", Corporate Social Responsibility and Environmental Management, Vol. 11 No. 1, pp. 1-11.

El-Kassar, A.N., Elgammal, W. and Bayoud, M.M. (2014), "Effect of internal audit function on corporate governance quality: evidence from Lebanon", International Journal of Corporate Governance, Vol. 5 Nos 1/2, pp. 103-117.

EL-Kassar, A.N., Messarra, L. and El-Gammal, W. (2015), "Effects of ethical practices on corporate governance in developing countries: evidence from Lebanon and Egypt", Corporate Ownership and Control, Vol. 12 No. 3, pp. 494-504.

Fahed-Sreih, J., Pistrui, D., Huang, W. and Welsch, H. (2010), "Family and cultural factors impacting entrepreneurship in war time Lebanon", International Journal of Entrepreneurship and Innovation Management, Vol. 12 No. 1, pp. 35-51.

Fahed-Sreih., J. (2008), "Distinctive trends, challenges, problems, and opportunities facing family businesses in the Middle East", in Gupta, V. (Ed.), Family Business Models from Around the World, Compendium on Family Owned Businesses - Culturally Sensitive Models of Family Business in the Middle East, The ICFAI University Press, Hyderabad, pp. 50-61.

Fornell, C. and Larcker, D. (1981), "Evaluating structural equation models with unobservable variables and measurement error", Journal of Marketing Research, Vol. 18, pp. 39-50.

Freeman, R.E. (1984), Strategic Management: A Stakeholder Approach, Pitman, Boston, MA.

Freeman, R.E. (2010), Strategic Management: A Stakeholder Approach, Cambridge University Press, Cambridge.

Gill, A. (2008), "Corporate governance as social responsibility: a research agenda”, Berkeley Journal of International Law, Vol. 26, p. 452.

Family-owned enterprises

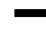


JOCM

31,1

Grant, G.H. (2003), "The evolution of corporate governance and its impact on modern corporate America", Management Decision, Vol. 41 No. 9, pp. 923-934.

Hambrick, D.C., Werder, A. and Zajac, E.J. (2008), "New directions in corporate governance research", Organization Science, Vol. 19 No. 1, pp. 381-385.

Idemudia, U. (2011), "Corporate social responsibility and developing countries moving the critical CSR research agenda in Africa forward", Progress in Development Studies, Vol. 11 No. 1, pp. 1-18.

International Finance Corporation (2017), "World Bank and Lebanese transparency association", Reference guidebook on the corporate governance of family owned business, Beirut, available at: www.transparency-lebanon.org/publications/foecgen.pdf

Jamali, D. and Mirshak, R. (2010), "Business-conflict linkages: revisiting MNCs, CSR, and conflict", Journal of Business Ethics, Vol. 93 No. 1, pp. 443-464.

Jamali, D., Lund-Thomsen and Jeppesen, S. (2015), "SMEs and CSR in developing countries", Business \& Society, Vol. 56 No. 1, pp. 11-22.

Jamali, D., Safieddine, A.M. and Rabbath, M. (2008), "Corporate governance and corporate social responsibility synergies and interrelationships", Corporate Governance: An International Review, Vol. 16 No. 5, pp. 443-459.

Jamali, D., Sidani, Y. and El-Asmar, K. (2009), "A three country comparative analysis of managerial CSR perspectives: insights from Lebanon, Syria and Jordan”, Journal of Business Ethics, Vol. 85 No. 1, pp. 173-192.

Jia, M. and Zhang, Z. (2013), "Managerial ownership and corporate social performance: evidence from privately owned Chinese firms' response to the Sichuan earthquake", Corporate Social Responsibility and Environmental Management, Vol. 20 No. 5, pp. 257-274.

Jo, H. and Harjoto, M.A. (2011), "Corporate governance and firm value: the impact of corporate social responsibility", Journal of Business Ethics, Vol. 103 No. 1, pp. 351-383.

Jones, G.R. (2010), Organizational Theory, Design, and Change, Pearson.

Kaslow, F.W. (2006), "Handbook of family business and family business consultation: A global perspective", Routledge.

Khan, A., Muttakin, M.B. and Siddiqui, J. (2013), "Corporate governance and corporate social responsibility disclosures: evidence from an emerging economy", Journal of Business Ethics, Vol. 114 No. 2, pp. 207-223.

Khan, H.U.Z. (2010), "The effect of corporate governance elements on corporate social responsibility (CSR) reporting: empirical evidence from private commercial banks of Bangladesh", International Journal of Law and Management, Vol. 52 No. 2, pp. 82-109.

Margolis, J.D. and Walsh, J.P. (2003), "Misery loves companies: rethinking social initiatives by business", Administrative Science Quarterly, Vol. 48 No. 1, pp. 265-305.

Mayer, C. (2013), "Why are we facing a crisis of trust in corporations?", available at: www.youtube.com/ watch?v=u1WU2G9M31I (accessed April 10, 2015).

Mitnick, B. (2013), “Origin of the theory of agency: an account by one of the theory's originators", available at: https://ssrn.com/abstract=1020378; http://dx.doi.org/10.2139/ssrn.1020378

Money, K. and Schepers, H. (2007), "Are CSR and corporate governance converging?: a view from boardroom directors and company secretaries in FTSE100 companies in the UK", Journal of General Management, Vol. 33 No. 2, pp. 1-11.

Nicolae, B.S. and Violeta, A.M. (2013), "Theories of corporate governance", Studia Universitatis Vasile Goldiş, Arad-Seria Ştiinţe Economice, Vol. V No. 12, pp. 117-128.

Ntim, C.G. and Soobaroyen, T. (2013), "Corporate governance and performance in socially responsible corporations: new empirical insights from a neo-institutional framework", Corporate Governance: An International Review, Vol. 21 No. 5, pp. 468-494.

Saidi, N. (2004), "Corporate governance in Mena countries: improving transparency and disclosure.", The Second Middle East and North Africa Regional Corporate Governance Forum, Beirut, pp. 1-130. 
Salloum, C.C., Azoury, N.M. and Azzi, T.M. (2013), "Board of directors' effects on financial distress evidence of family owned businesses in Lebanon", International Entrepreneurship and Management Journal, Vol. 9 No. 1, pp. 59-75.

Schilling, M.A. (2000), "Decades ahead of her time: advancing stakeholder theory through the ideas of Mary Parker Follett”, Journal of Management History, Vol. 6 No. 5, pp. 224-242.

Shleifer, A. and Vishny, R.W. (1997), "A survey of corporate governance", The Journal of Finance, Vol. 52 No. 2, pp. 737-783.

Smith, A. (1937), The Wealth of Nations first published: 1776, William Strahan, Thomas Cadell, p. 421.

Smith, J. (2014), "The companies with the best CSR reputations", available at: www.forbes.com /sites/jacquelynsmith/2012/12/10/the-companies-with-the-best-csr-reputations/ (accessed March 11, 2015).

Stern, R.N. and Barley, S.R. (1996), “Organizations and social systems: organization theory's neglected mandate", Administrative Science Quarterly, Vol. 41 No. 1, pp. 146-162.

Tosi, H.L., Werner, S., Katz, J. and Gomez-Mejia, L.R. (2000), "How much does performance matter? A meta-analysis of CEO pay studies", Journal of Management, Vol. 26 No. 2, pp. 301-339.

Tuan, L.T. (2012), "Corporate social responsibility, ethics, and corporate governance", Social Responsibility Journal, Vol. 8 No. 4, pp. 547-560.

Wood, D. (1991), "Corporate social performance revisited", The Academy of Management Review, Vol. 16 No. 4, pp. 691-718.

Zeckhauser, R.J. and Pratt, J.W. (1985), Principals and Agents: The Structure of Business, Harvard Business School, Boston, MA.

\section{Further reading}

Denis, D.K. and McConnell, J.J. (2003), "International corporate governance", Journal of Financial and Quantitative Analysis, Vol. 38 No. 1, pp. 1-36.

Friedman, M. (1970), "The social responsibility of business is to increase its profits", The New York Times, September 13, pp. 173-178.

\section{Corresponding author}

Abdul-Nasser El-Kassar can be contacted at: abdulnasser.kassar@lau.edu.lb

\section{Family-owned enterprises}

